OPEN ACCESS

Edited by: Ishwar Parhar,

Monash University, Malaysia

Reviewed by:

Etienne Challet,

Centre National de la Recherche

Scientifique, France

Kazuyuki Shinohara,

Nagasaki University, Japan

*Correspondence:

Toshiya Funabashi,

Department of Physiology, St.

Marianna University School of Medicine, 2-16-1 Sugao, Miyamae-ku,

Kawasaki 216-8511, Japan toshiya@marianna-u.ac.jp

Specialty section

This article was submitted to Neuroendocrine Science, a section of the journal Frontiers in Neuroscience

Received: 18 September 2014 Accepted: 02 March 2015 Published: 30 March 2015

Citation: Fukushima A, Hagiwara H, Fujioka H, Kimura F, Akema $T$ and Funabashi $T$

(2015) Sex differences in feeding behavior in rats: the relationship with neuronal activation in the hypothalamus. Front. Neurosci. 9:88. doi: 10.3389/fnins.2015.00088

\section{Sex differences in feeding behavior in rats: the relationship with neuronal activation in the hypothalamus}

\author{
Atsushi Fukushima ${ }^{1}$, Hiroko Hagiwara ${ }^{1,2}$, Hitomi Fujioka ${ }^{1}$, Fukuko Kimura ${ }^{2}$, \\ Tatsuo Akema ${ }^{1}$ and Toshiya Funabashi ${ }^{1,2 *}$ \\ 1 Department of Physiology, St. Marianna University School of Medicine, Kawasaki, Japan, ${ }^{2}$ Department of Physiology, \\ Yokohama City University Graduate School of Medicine, Yokohama, Japan
}

There is general agreement that the central nervous system in rodents differs between sexes due to the presence of gonadal steroid hormone during differentiation. Sex differences in feeding seem to occur among species, and responses to fasting (i.e., starvation), gonadal steroids (i.e., testosterone and estradiol), and diet (i.e., western-style diet) vary significantly between sexes. The hypothalamus is the center for controlling feeding behavior. We examined the activation of feeding-related peptides in neurons in the hypothalamus. Phosphorylation of cyclic AMP response element-binding protein (CREB) is a good marker for neural activation, as is the Fos antigen. Therefore, we predicted that sex differences in the activity of melanin-concentrating hormone $(\mathrm{MCH})$ neurons would be associated with feeding behavior. We determined the response of $\mathrm{MCH}$ neurons to glucose in the lateral hypothalamic area (LHA) and our results suggested $\mathrm{MCH}$ neurons play an important role in sex differences in feeding behavior. In addition, fasting increased the number of orexin neurons harboring phosphorylated CREB in female rats (regardless of the estrous day), but not male rats. Glucose injection decreased the number of these neurons with phosphorylated CREB in fasted female rats. Finally, under normal spontaneous food intake, $\mathrm{MCH}$ neurons, but not orexin neurons, expressed phosphorylated CREB. These sex differences in response to fasting and glucose, as well as under normal conditions, suggest a vulnerability to metabolic challenges in females.

Keywords: sex differences and hormone effects, feeding behavior, rats, CREB, melanin-concentrating hormone, orexin, hypothalamus

\section{Introduction}

There is general agreement that the central nervous system in rodents differs between sexes due to the presence of gonadal steroid hormone during differentiation (Phoenix et al., 1959; Gorski and Barraclough, 1963). The organizing action of prenatally administered testosterone is evident on tissues that mediate mating behavior in female rodents (Arnold and Gorski, 1984). However, sexual differentiation of the brain is more complicated (McCarthy, 2008; Schwarz and McCarthy, 2008a; Nugent and McCarthy, 2011; Wu and Shah, 2011; Lenz et al., 2013) than once thought, even in rodents. 


\section{Sexual Differentiation of the Hypothalamus: Rodents and Primates}

For example, one apparent sexual difference of the hypothalamus is the mechanism for controlling gonadotropin secretion. Differentiation is certainly present in rodents (Butcher et al., 1974; Kalra and Kalra, 1983); however, in primates, the sexual differentiation of the pituitary function related to gonadotropin secretion is different from that in rodents (Karsch et al., 1973). Luteinizing hormone induction due to positive feedback from estrogen is evident in female, but not male, rodents (Kalra, 1993); although, in primates, both sexes secrete luteinizing hormone in response to estrogen (Karsch et al., 1973; Hodges, 1980). Estrogen positive feedback is capable of inducing luteinizing hormone secretion even in castrated human males, suggesting that exposure of the human brain to androgen during the early perinatal period does not completely induce a sexually dimorphic mechanism for controlling gonadotropin secretion (Barbarino and De Marinis, 1980). Alternatively, the apparent difference in sexual differentiation between primates and rodents may be due to differences between the hypothalamus- and pituitary-mediated control of gonadotropin secretion, since Fos is not expressed in response to gonadotropin-releasing hormone in monkeys (Witkin et al., 1994) but its expression is essential in rodents (Hoffman et al., 1990; Lee et al., 1990b,a).

\section{Sex Differences in Feeding Behavior}

On the other hand, there seems to be general sex differences in feeding among species. The hypothalamus is the center for controlling feeding behavior (Hervey, 1959; Bernardis and Bellinger, 1996). According to glucostatic theory, one of the factors controlling feeding is glucose (Mayer et al., 1952). As shown in Figure 1, glucose affects the control of feeding via a mechanism in the hypothalamus, which includes the ventromedial hypothalamus and the lateral hypothalamic area (LHA) (Oomura et al., 1964, 1974). Once it was determined that fat tissues secrete feeding inhibitory hormone in the response to energy consumption, the mechanism for feeding control drastically changed (Friedman, 2004). The hormone leptin is secreted from fat tissue and strongly inhibits feeding by controlling the neurons in the arcuate nucleus of the hypothalamus through its receptors (Friedman, 2009). Although the feeding control mechanism remains an important function of the hypothalamus (Anand and Brobeck, 1951; Hervey, 1959; Bernardis and Bellinger, 1996; King, 2005; Dietrich and Horvath, 2011), a recent hypothesis is that the first step involves the arcuate nucleus of the hypothalamus, which then controls the LHA and the periventricular nucleus (Koch and Horvath, 2014; Sousa-Ferreira et al., 2014).

There is a significant sex difference in taste preference (Valenstein et al., 1967). The effect of hypothalamic lesions on feeding also differs according to sex (Valenstein et al., 1969), suggesting there is a potential sex-specific feeding pattern in rats (Laviano et al., 1996). Metabolic states profoundly affect reproduction (Wade et al., 1996), and the responses to factors that alter feeding behavior, such as a high-fat diet (Uhley et al., 1997), fasting (Varma et al., 2001; Gayle et al., 2006), and leptin activity

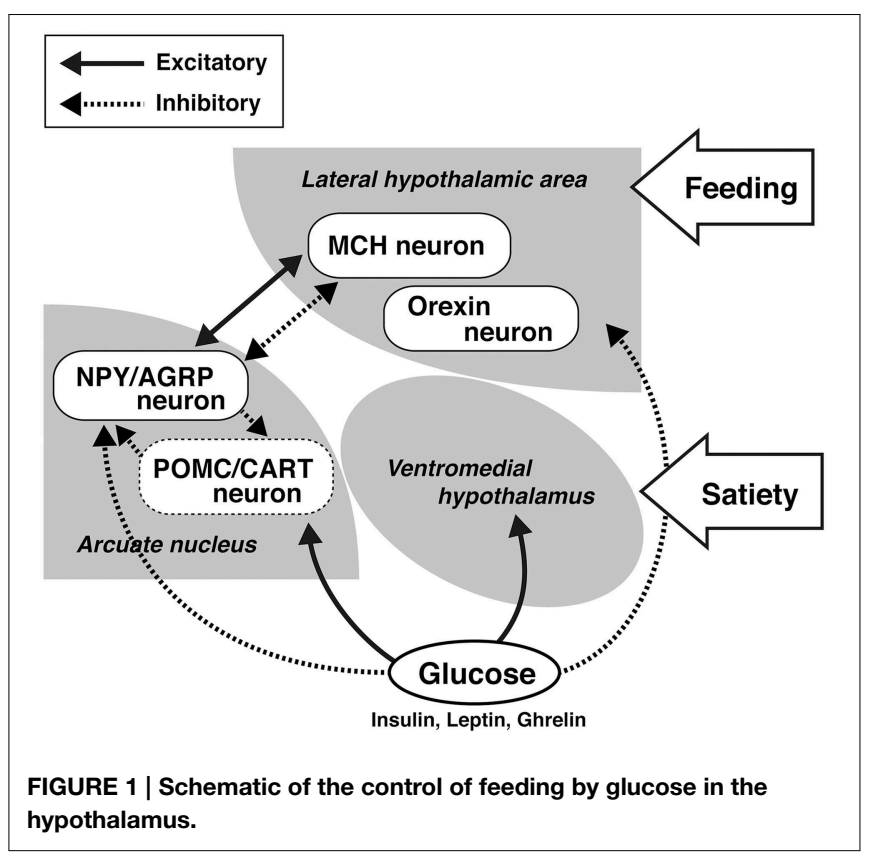

(Loh et al., 2011), are sex related. These sex-based differences in feeding behavior are probably the result of androgens present during sexual differentiation (Madrid et al., 1993; Schwarz and McCarthy, 2008b).

Importantly, these sex differences are also found in humans. In anorexia nervosa, there is a significant difference in morbidity between sexes (Geary, 2001; Schneider, 2006). The human hypothalamus is sexually differentiated (Swaab et al., 2001; Chung et al., 2002), as is food-related behavior in humans (Schneider, 2006; Zandian et al., 2011). Many behaviors in primates differ between sexes (Wilson and Davies, 2007; Hines, 2010) and may be related to the hormonal environment during sexual differentiation (Berenbaum and Beltz, 2011).

\section{Sex Differences in Feeding in Rodents}

The sex differences in the feeding behavior in rodents, including meal frequency and meal duration, were first determined using an automated feeding pattern analyzer (Meguid et al., 1990; Hyun et al., 1997). We confirmed that meal duration, but not meal frequency was significantly shorter in females than in males, as shown in Figure 2 (Funabashi et al., 2009) thus, there is a significant sex difference in feeding behavior. Male rodents are larger than females, in part due to the effects of testosterone (Petersen, 1978; Czaja, 1984; Asarian and Geary, 2006), as illustrated in Figure 3. On the other hand, estrogen reduces feeding (Eckel, 2004; Acosta-Martinez et al., 2007), probably via the ventromedial hypothalamus (Musatov et al., 2007; Butera, 2010; Xu et al., 2011) These effects of steroid hormones were demonstrated by gonadectomies (Kakolewski et al., 1968; Czaja, 1984). The body weight and food consumption in intact female rats were reduced when the effects of estrogen and progesterone were large (Tarttelin and Gorski, 1971). That is, at the time of ovulation when 
estrogen is high (Butcher et al., 1974), food intake was small and, as a result, body weight decreased in rats (Shimizu and Bray, 1993), bovine (Imakawa et al., 1986), and bamboo (Bielert and Busse, 1983) and rhesus monkeys (Kemnitz et al., 1989). These results illustrated that estrogen acts as a reducing factor of eating; therefore, estrogen is a target for reducing feeding behavior (Butera, 2010; Xu et al., 2011). Interestingly, male mice were more susceptible to high-fat induced obesity, known as experimentally induced obesity by diet (see review by Lai et al., 2014) than female mice (Nishikawa et al., 2007; Zammaretti et al., 2007; Hwang et al., 2010), and this was also the case with rats (Acosta-Martinez et al., 2007).

On the other hand, the effects of food deprivation in males and females are complicated. In general, adaption to food deprivation is important to survival in animals. Thus, rodents exhibit adaptive biochemical and physiological responses to
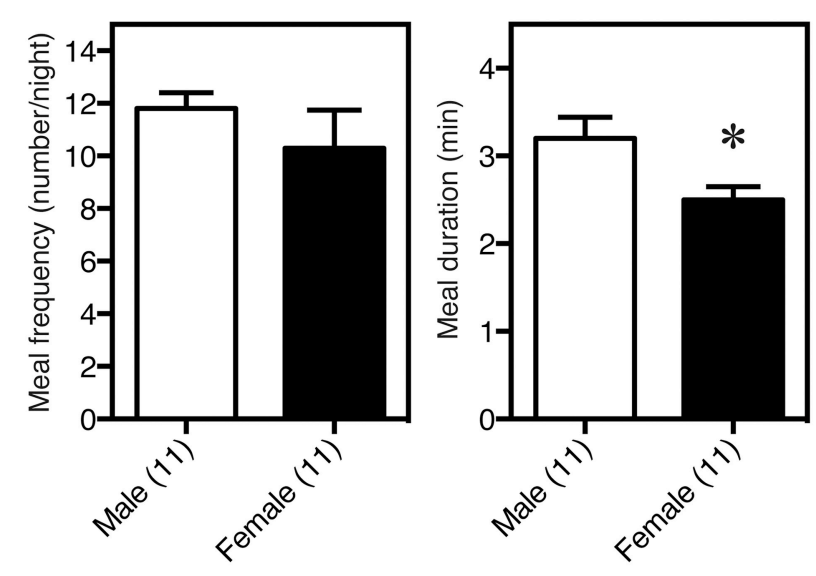

FIGURE 2 | Sex difference in feeding behavior, determined with an automated feeding pattern analyzer. Meal duration, but not frequency, was significantly shorter in females than in males. ${ }^{\star} P<0.05$. food deprivation. For instance, rodents reduce metabolism when deprived of food (see review by Wang et al., 2006). Of course, the amount of food consumed after fasting, the rebound eating, is increased soon after. Although the total amount of food consumption remained higher than that seen in nonfasted rats, the rate of consumption declined for the next $9 \mathrm{~h}$ (Ji and Friedman, 1999). This means that, during starvation, energy expenditure is decreased and energy efficiency increased when refeeding occurs soon after fasting has stopped (Robin et al., 2008). Alternatively, rebound eating after caloric restriction is different among species (Evans et al., 2005).

Interesting evidence is that sex-specific fasting effects. Fasting for $12 \mathrm{~h}$ increased the total daily food consumption during the refeeding period in both male and female rats, but female rats show a greater increase in the first $24 \mathrm{~h}$ food intake than males. In addition, fasting induced a greater increase in plasma ghrelin levels in female rats compared with male rats (Gayle et al., 2006). Further, there were sex differences in the response to dietary disruption (Martin et al., 2007). We found that rebound eating after fasting was more prompt in female rats than in male rats (Funabashi et al., 2009).

\section{Phosphorylation of CREB in the Hypothalamus}

We sought to determine whether feeding-related peptides in neurons in the hypothalamus were activated. The Fos antigen (Sheng et al., 1990) and phosphorylation of cyclic AMP response element-binding protein (CREB) (Mayr and Montminy, 2001; Lonze and Ginty, 2002; Carlezon et al., 2005) are good markers for neural activation. Increasing cyclic AMP induced robust feeding (Gillard et al., 1998), suggesting that upregulation of a cyclic AMP-mediated cascade induces feeding. Indeed, neuropeptide $\mathrm{Y}$ acts as an orexinergic peptide, increasing CREB activity in the rat hypothalamus (Sheriff et al., 1997; Gillard et al., 1998)

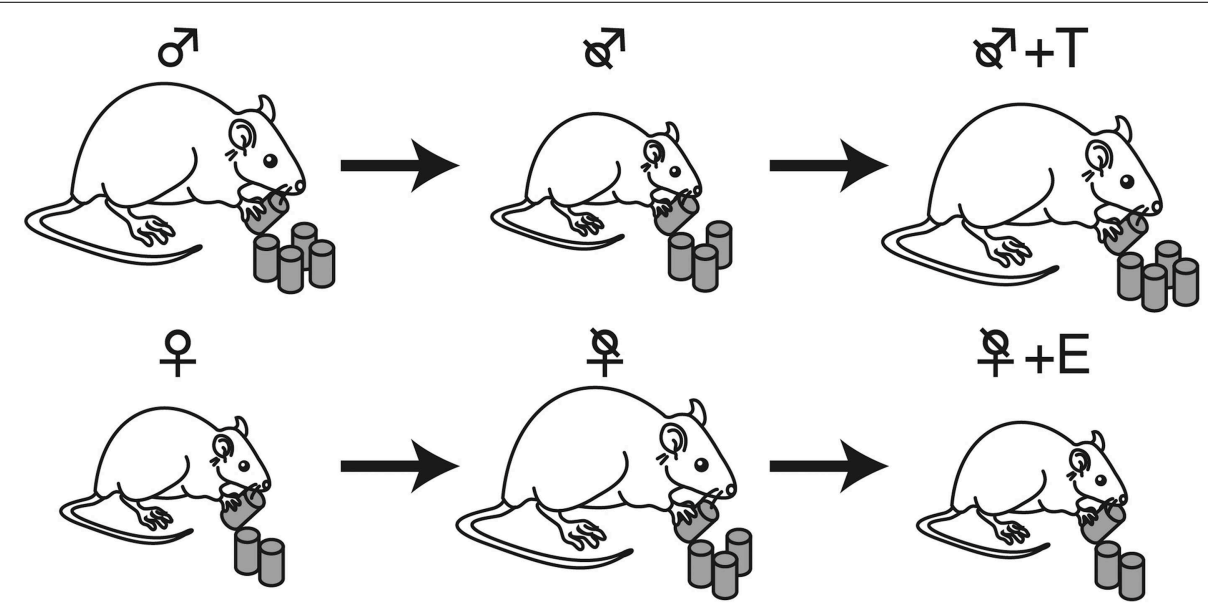

FIGURE 3 | Effects of gonadectomy and gonadal steroid hormones on feeding. Males $\left(\sigma^{7}\right)$ eat more than females (o), but gonadectomy $(\backslash)$ had the opposite effect: castration of males resulted in weight loss because of decreased eating, while castration of females increased body weight due to hyperphagia. These changes were restored by testosterone (T) and estrogen (E) replacement, respectively. 
and downregulation of CREB induction attenuates leptin inhibition in neurons expressing neuropeptide $Y$ (Shimizu-Albergine et al., 2001). Thus, CREB phosphorylation is a reliable marker for neuronal activity related to feeding behavior (Gayle et al., 2006; Martin et al., 2007; Funabashi et al., 2009). We attempted to attenuate CREB activity in the hypothalamus and evaluated the sex difference.

\section{Melanin-Concentrating Hormone and CREB Phosphorylation in the LHA}

Melanin-concentrating hormone $(\mathrm{MCH})$ neurons in the LHA (Bittencourt et al., 1992) are involved in feeding behavior (Qu et al., 1996; De Lecea et al., 1998). Mice lacking MCH neurons are hypophagic (Shimada et al., 1998), and $\mathrm{MCH}$ receptor antagonists decrease feeding (Kowalski et al., 2004). Therefore, we predicted that sex differences in the activity of $\mathrm{MCH}$ neurons would be associated with feeding behavior. We determined the response to glucose of $\mathrm{MCH}$ neurons in the LHA using phosphorylated CREB as a marker of neural activity (Mogi et al., 2005). Intact male rats and female rats at various days of the estrous cycle were fasted for $48 \mathrm{~h}$ and injected with glucose. Thereafter, the rats' brains were analyzed by immunohistochemistry for $\mathrm{MCH}$ and phosphorylated CREB. Fasting for $48 \mathrm{~h}$ increased the percentage of MCH neurons in the LHA harboring phosphorylated CREB in both sexes, but glucose injection decreased the ratio of these double-stained cells more promptly in females than in males. Gonadectomy enhanced and attenuated the response of $\mathrm{MCH}$ neurons in males and females, respectively. Furthermore, steroid-hormone replacement in both males and females restored the response of $\mathrm{MCH}$ neurons to glucose. These results suggested that $\mathrm{MCH}$ neurons play an important role in sex differences in feeding behavior. It was later demonstrated that $\mathrm{MCH}$ stimulates feeding behavior and its receptor antagonist attenuates it in relation to palatability (Morens et al., 2005). Thus, MCH may be an important regulator of the intake of palatable foods such as sweet sugar water (Sakamaki et al., 2005; Baird et al., 2008; Fukushima et al., 2014), and MCH neurons are likely more active in females than in males. Estradiol may attenuate the feeding-stimulated effects of $\mathrm{MCH}$ in females (Messina et al., 2006), which vary during the estrous cycle (Santollo and Eckel, 2008).

\section{Orexin and CREB Phosphorylation in the LHA}

Since orexin neurons are also involved in feeding (Broberger et al., 1998; Sakurai et al., 1998; Bayer et al., 2005; Burdakov et al., 2005), we looked for a possible sex difference in the response of orexin neurons in the LHA to fasting (Funabashi et al., 2009). The experimental procedures were similar to those indicated above. Fasting increased the number of orexin neurons harboring phosphorylated CREB in female rats (regardless of the estrous day), but not in male rats; thus, there was a significant sex difference. Importantly, the action of orexin in feeding behavior is distinct from $\mathrm{MCH}$. Glucose injection in fasted rats decreased the number of orexin neurons expressing phosphorylated CREB in female rats. These sex differences in the response of orexin neurons to fasting suggest a higher sensitivity of female hypothalamus to metablic cues. We also performed experiments under normal spontaneous food intake and found the MCH neurons, but not orexin neurons, expressed phosphorylated CREB. Again, attenuation seemed to occur faster in females than in males.

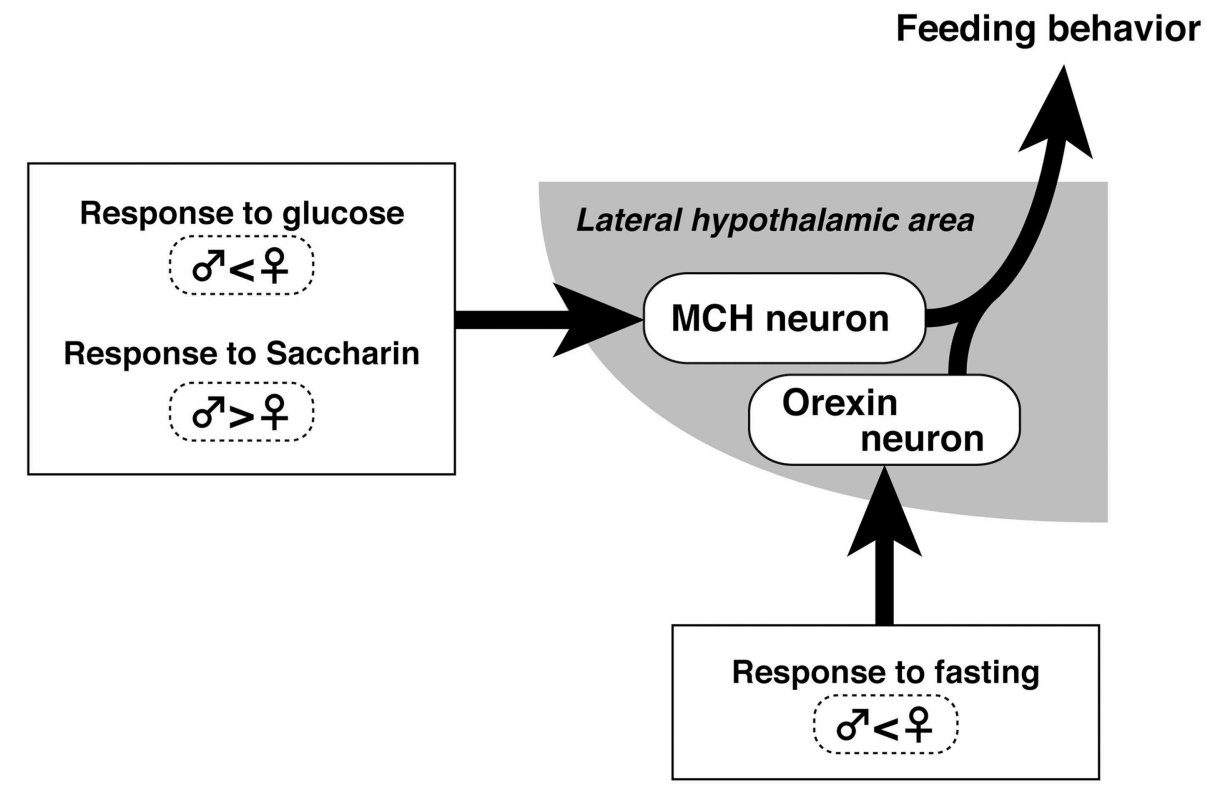

FIGURE 4 | Schematic of sex differences in $\mathrm{MCH}$ and orexin neuronal activity related to feeding control in the hypothalamus. 


\section{Conclusions and Future Directions}

We hypothesized that $\mathrm{MCH}$ neurons respond to nutritionrelated feeding, but the feeding-related activity of orexin neurons is not evident unless hunger is accompanied by a bad emotion, such as that caused by fasting (Figure 4). Thus, the desire to eat under normal conditions does not drive orexin neurons, but it does drive $\mathrm{MCH}$ neurons. In line with this hypothesis, orexin inhibited pulsatile luteinizing hormone secretion under emotional conditions, but this effect was absent if food was available (Furuta et al., 2010). Future studies should determine what kind

\section{References}

Acosta-Martinez, M., Horton, T., and Levine, J. E. (2007). Estrogen receptors in neuropeptide Y neurons: at the crossroads of feeding and reproduction. Trends Endocrinol. Metab. 18, 48-50. doi: 10.1016/j.tem.2006.12.001

Anand, B. K., and Brobeck, J. R. (1951). Localization of a "feeding center" in the hypothalamus of the rat. Proc. Soc. Exp. Biol. Med. 77, 323-324.

Arnold, A. P., and Gorski, R. A. (1984). Gonadal steroid induction of structural sex differences in the central nervous system. Annu. Rev. Neurosci. 7, 413-442. doi: 10.1146/annurev.ne.07.030184.002213

Asarian, L., and Geary, N. (2006). Modulation of appetite by gonadal steroid hormones. Philos. Trans. R. Soc. Lond. B Biol. Sci. 361, 1251-1263. doi: 10.1098/rstb.2006.1860

Baird, J. P., Rios, C., Loveland, J. L., Beck, J., Tran, A., and Mahoney, C. E. (2008). Effects of hindbrain melanin-concentrating hormone and neuropeptide $\mathrm{Y}$ administration on licking for water, saccharin, and sucrose solutions. Am. J. Physiol. Regul. Integr. Comp. Physiol. 294, R329-R343. doi: 10.1152/ajpregu.00611.2006

Barbarino, A., and De Marinis, L. (1980). Estrogen induction of luteinizing hormone release in castrated adult human males. J. Clin. Endocrinol. Metab. 51, 280-286.

Bayer, L., Eggermann, E., Serafin, M., Grivel, J., Machard, D., Muhlethaler, M., et al. (2005). Opposite effects of noradrenaline and acetylcholine upon hypocretin/orexin versus melanin concentrating hormone neurons in rat hypothalamic slices. Neuroscience 130, 807-811. doi: 10.1016/j.neuroscience.2004. 10.032

Berenbaum, S. A., and Beltz, A. M. (2011). Sexual differentiation of human behavior: effects of prenatal and pubertal organizational hormones. Front. Neuroendocrinol. 32, 183-200. doi: 10.1016/j.yfrne.2011.03.001

Bernardis, L. L., and Bellinger, L. L. (1996). The lateral hypothalamic area revisited: ingestive behavior. Neurosci. Biobehav. Rev. 20, 189-287. doi: 10.1016/01497634(95)00015-1

Bielert, C., and Busse, C. (1983). Influences of ovarian hormones on the food intake and feeding of captive and wild female chacma baboons (Papio ursinus). Physiol. Behav. 30, 103-111.

Bittencourt, J. C., Presse, F., Arias, C., Peto, C., Vaughan, J., Nahon, J. L., et al. (1992). The melanin-concentrating hormone system of the rat brain: an immuno- and hybridization histochemical characterization. J. Comp. Neurol. 319, 218-245. doi: 10.1002/cne.903190204

Broberger, C., De Lecea, L., Sutcliffe, J. G., and Hokfelt, T. (1998). Hypocretin/orexin- and melanin-concentrating hormone-expressing cells form distinct populations in the rodent lateral hypothalamus: relationship to the neuropeptide Y and agouti gene-related protein systems. J. Comp. Neurol. 402, 460-474. doi: 10.1002/(SICI)1096-9861(19981228)402:4<460::AID$\mathrm{CNE} 3>3.0 . \mathrm{CO} ; 2-\mathrm{S}$

Burdakov, D., Gerasimenko, O., and Verkhratsky, A. (2005). Physiological changes in glucose differentially modulate the excitability of hypothalamic melaninconcentrating hormone and orexin neurons in situ. J. Neurosci. 25, 2429-2433. doi: 10.1523/JNEUROSCI.4925-04.2005

Butcher, R. L., Collins, W. E., and Fugo, N. W. (1974). Plasma concentration of LH, $\mathrm{FSH}$, prolactin, progesterone and estradiol-17b throughout the 4-day estrous cycle of the rat. Endocrinology 94, 1704-1708. of emotion is associated with fasting and the neural basis for this mechanism.

\section{Acknowledgments}

This work was supported by a Grant-in-Aid for Scientific Research (C: 19590229 to TF) from the Ministry of Education, Culture, Sports, Science, and Technology, Japan, and the Yokohama Foundation for Advancement of Medical Science, Umehara.

Butera, P. C. (2010). Estradiol and the control of food intake. Physiol. Behav. 99, 175-180. doi: 10.1016/j.physbeh.2009.06.010

Carlezon, W. A. Jr., Duman, R. S., and Nestler, E. J. (2005). The many faces of CREB. Trends Neurosci. 28, 436-445. doi: 10.1016/j.tins.2005.06.005

Chung, W. C., De Vries, G. J., and Swaab, D. F. (2002). Sexual differentiation of the bed nucleus of the stria terminalis in humans may extend into adulthood. J. Neurosci. 22, 1027-1033.

Czaja, J. A. (1984). Sex differences in the activational effects of gonadal hormones on food intake and body weight. Physiol. Behav. 33, 553-558.

De Lecea, L., Kilduff, T. S., Peyron, C., Gao, X., Foye, P. E., Danielson, P. E., et al. (1998). The hypocretins: hypothalamus-specific peptides with neuroexcitatory activity. Proc. Natl. Acad. Sci. U.S.A. 95, 322-327.

Dietrich, M. O., and Horvath, T. L. (2011). Synaptic plasticity of feeding circuits: hormones and hysteresis. Cell 146, 863-865. doi: 10.1016/j.cell.2011.08.031

Eckel, L. A. (2004). Estradiol: a rhythmic, inhibitory, indirect control of meal size. Physiol. Behav. 82, 35-41. doi: 10.1016/j.physbeh.2004.04.023

Evans, S. A., Messina, M. M., Knight, W. D., Parsons, A. D., and Overton, J. M. (2005). Long-evans and sprague-dawley rats exhibit divergent responses to refeeding after caloric restriction. Am. J. Physiol. Regul. Integr. Comp. Physiol. 288, R1468-R1476. doi: 10.1152/ajpregu.00602.2004

Friedman, J. M. (2004). Modern science versus the stigma of obesity. Nat. Med. 10, 563-569. doi: 10.1038/nm0604-563

Friedman, J. M. (2009). Leptin at 14 y of age: an ongoing story. Am. J. Clin. Nutr. 89, 973S-979S. doi: 10.3945/ajcn.2008.26788B

Fukushima, A., Hagiwara, H., Yoshioka, N., Kimura, F., Akema, T., and Funabashi, T. (2014). Expression of phosphorylated cyclic AMP response element-binding protein in melanin-concentrating hormone neurons and orexin neurons in male and female rats during ad-libitum feeding. Neuroreport $25,766-770$. doi 10.1097/WNR.0000000000000172

Funabashi, T., Hagiwara, H., Mogi, K., Mitsushima, D., Shinohara, K., and Kimura, F. (2009). Sex differences in the responses of orexin neurons in the lateral hypothalamic area and feeding behavior to fasting. Neurosci. Lett. 463, 31-34. doi: 10.1016/j.neulet.2009.07.035

Furuta, M., Mitsushima, D., Shinohara, K., Kimura, F., and Funabashi, T. (2010). Food availability affects orexin a/ hypocretin-1-induced inhibition of pulsatile luteinizing hormone secretion in female rats. Neuroendocrinology 91, 41-47. doi: 10.1159/000257408

Gayle, D. A., Desai, M., Casillas, E., Beloosesky, R., and Ross, M. G. (2006). Gender-specific orexigenic and anorexigenic mechanisms in rats. Life Sci. 79, 1531-1536. doi: 10.1016/j.lfs.2006.04.015

Geary, N. (2001). Sex differences in disease anorexia. Nutrition 17, 499-507. doi: 10.1016/S0899-9007(01)00588-3

Gillard, E. R., Khan, A. M., Grewal, R. S., Mouradi, B., Wolfsohn, S. D., and Stanley, B. G. (1998). The second messenger cAMP elicits eating by an anamically specific action in the perifornical hypothalamus. J. Neurosci. 18, 2646-2652.

Gorski, R. A., and Barraclough, C., A. (1963). Effects of low dosages of androgen on the differentiation of hypothalamic regulatory control of ovulation in the rat. Endocrinology 73, 210-216.

Hervey, G. R. (1959). The effects of lesions in the hypothalamus in parabiotic rats. J. Physiol. 145, 336-352.

Hines, M. (2010). Sex-related variation in human behavior and the brain. Trends Cognit. Sci. 14, 448-456. doi: 10.1016/j.tics.2010.07.005 
Hodges, J. K. (1980). Regulation of oestrogen-induced LH release in male and female marmoset monkeys (Callithrix jacchus). J. Reprod. Fertil. 60, 389-398.

Hoffman, G. E., Lee, W. S., Attardi, B., Yann, V., and Fitzsimmons, M. D. (1990). Luteinizing hormone-releasing hormone neurons express c-fos antigen after steroid activation. Endocrinology 126, 1736-1741. doi: 10.1210/endo-1263-1736

Hwang, L. L., Wang, C. H., Li, T. L., Chang, S. D., Lin, L. C., Chen, C. P., et al. (2010). Sex differences in high-fat diet-induced obesity, metabolic alterations and learning, and synaptic plasticity deficits in mice. Obesity (Silver Spring) 18, 463-469. doi: 10.1038/oby.2009.273

Hyun, Y., Ellis, M., McKeith, F. K., and Wilson, E. R. (1997). Feed intake pattern of group-housed growing-finishing pigs monitored using a computerized feed intake recording system. J. Anim. Sci. 75, 1443-1451.

Imakawa, K., Day, M. L., Zalesky, D. D., Garcia-Winder, M., Kittok, R. J., and Kinder, J. E. (1986). Influence of dietary-induced weight changes on serum luteinizing hormone, estrogen and progesterone in the bovine female. Biol. Reprod. 35, 377-384.

Ji, H., and Friedman, M. I. (1999). Compensatory hyperphagia after fasting tracks recovery of liver energy status. Physiol. Behav. 68, 181-186.

Kakolewski, J. W., Cox, V. C., and Valenstein, E. S. (1968). Sex differences in body-weight change following gonadectomy of rats. Psychol. Rep. 22, 547-554.

Kalra, S. P. (1993). Mandatory neuropeptide-steroid signaling for the preovulatory luteinizing hormone-releasing hormone discharge. Endocr. Rev. 14, 507-538. doi: 10.1210/edrv-14-5-507

Kalra, S. P., and Kalra, P. S. (1983). Neural regulation of luteinizing hormone secretion in the rat. Endocr. Rev. 4, 311-351.

Karsch, F. J., Dierschke, D. J., and Knobil, E. (1973). Sexual differentiation of pituitary function: apparent difference bewteen primates and rodents. Science 179, 484-486.

Kemnitz, J. W., Gibber, J. R., Lindsay, K. A., and Eisele, S. G. (1989). Effects of ovarian hormones on eating behaviors, body weight, and glucoregulation in rhesus monkeys. Horm. Behav. 23, 235-250.

King, P. J. (2005). The hypothalamus and obesity. Curr. Drug Targets 6, 225-240. doi: $10.2174 / 1389450053174587$

Koch, M., and Horvath, T. L. (2014). Molecular and cellular regulation of hypothalamic melanocortin neurons controlling food intake and energy metabolism. Mol. Psychiatry 19, 752-761. doi: 10.1038/mp.2014.30

Kowalski, T. J., Farley, C., Cohen-Williams, M. E., Varty, G., and Spar, B. D. (2004). Melanin-concentrating hormone-1 receptor antagonism decreases feeding by reducing meal size. Eur. J. Pharmacol. 497, 41-47. doi: 10.1016/j.ejphar.2004.06.027

Lai, M., Chandrasekera, P. C., and Barnard, N. D. (2014). You are what you eat, or are you? the challenges of translating high-fat-fed rodents to human obesity and diabetes. Nutr. Diabetes 4, e135. doi: 10.1038/nutd.2014.30

Laviano, A., Meguid, M. M., Gleason, J. R., Yang, Z. J., and Renvyle, T. (1996). Comparison of long-term feeding pattern between male and female Fischer 344 rats: influence of estrous cycle. Am. J. Physiol. 270, R413-R419.

Lee, W. S., Smith, M. S., and Hoffman, G. E. (1990a). Luteinizing hormonereleasing hormone neurons express Fos protein during the proestrous surge of luteinizing hormone. Proc. Natl. Acad. Sci. U.S.A. 87, 5163-5167.

Lee, W. S., Smith, M. S., and Hoffman, G. E. (1990b). Progesterone enhances the surge of luteinizing hormone by increasing the activation of luteinizing hormone-releasing hormone neurons. Endocrinology 127, 2604-2606. doi: 10.1210/endo-127-5-2604

Lenz, K. M., Nugent, B. M., Haliyur, R., and McCarthy, M. M. (2013). Microglia are essential to masculinization of brain and behavior. J. Neurosci. 33, 2761-2772. doi: 10.1523/JNEUROSCI.1268-12.2013

Loh, K., Fukushima, A., Zhang, X., Galic, S., Briggs, D., Enriori, P. J., et al. (2011). Elevated hypothalamic TCPTP in obesity contributes to cellular leptin resistance. Cell Metab. 14, 684-699. doi: 10.1016/j.cmet.2011.09.011

Lonze, B. E., and Ginty, D. D. (2002). Function and regulation of CREB family transcription factors in the nervous system. Neuron 35, 605-623. doi: 10.1016/S0896-6273(02)00828-0

Madrid, J. A., Lopez-Bote, C., and Martin, E. (1993). Effect of neonatal androgenization on the circadian rhythm of feeding behavior in rats. Physiol. Behav. 53, 329-335. doi: 10.1016/0031-9384(93)90213-Y

Martin, B., Pearson, M., Kebejian, L., Golden, E., Keselman, A., Bender, M., et al. (2007). Sex-dependent metabolic, neuroendocrine, and cognitive responses to dietary energy restriction and excess. Endocrinology 148, 4318-4333. doi: 10.1210/en.2007-0161

Mayer, J., Bates, M. W., and Van Itallie, T. B. (1952). Blood sugar and food intake in rats with lesions of the anterior hypothalamus. Metabolism 1, 340-348.

Mayr, B., and Montminy, M. (2001). Transcriptional regulation by the phosphorylation-dependent factor CREB. Nat. Rev. Mol. Cell. Biol. 2, 599-609. doi: $10.1038 / 35085068$

McCarthy, M. (2008). Estradiol and the developing brain. Physiol Rev. 88, 91-124. doi: $10.1152 /$ physrev.00010.2007

Meguid, M. M., Kawashima, Y., Campos, A. C., Gelling, P. D., Hill, T. W., Chen, T. Y., et al. (1990). Automated computerized rat eater meter: description and application. Physiol. Behav. 48, 759-763. doi: 10.1016/0031-9384(90)90222-P

Messina, M. M., Boersma, G., Overton, J. M., and Eckel, L. A. (2006). Estradiol decreases the orexigenic effect of melanin-concentrating hormone in ovariectomized rats. Physiol. Behav. 88, 523-528. doi: 10.1016/j.physbeh.2006.05.002

Mogi, K., Funabashi, T., Mitsushima, D., Hagiwara, H., and Kimura, F. (2005). Sex difference in the response of melanin-concentrating hormone neurons in the lateral hypothalamic area to glucose, as revealed by the expression of phosphorylated cyclic adenosine $3^{\prime}, 5^{\prime}$-monophosphate response element-binding protein. Endocrinology 146, 3325-3333. doi: 10.1210/en.2005-0078

Morens, C., Norregaard, P., Receveur, J. M., Van Dijk, G., and Scheurink, A. J. (2005). Effects of MCH and a MCH1-receptor antagonist on (palatable) food and water intake. Brain Res. 1062, 32-38. doi: 10.1016/j.brainres.2005. 09.005

Musatov, S., Chen, W., Pfaff, D. W., Mobbs, C. V., Yang, X. J., Clegg, D. J., et al. (2007). Silencing of estrogen receptor alpha in the ventromedial nucleus of hypothalamus leads to metabolic syndrome. Proc. Natl. Acad. Sci. U.S.A. 104, 2501-2506. doi: 10.1073/pnas.0610787104

Nishikawa, S., Yasoshima, A., Doi, K., Nakayama, H., and Uetsuka, K. (2007). Involvement of sex, strain and age factors in high fat diet-induced obesity in C57BL/6J and BALB/cA mice. Exp. Anim. 56, 263-272. doi: 10.1538/expanim. 56.263

Nugent, B. M., and McCarthy, M. M. (2011). Epigenetic underpinnings of developmental sex differences in the brain. Neuroendocrinology 93, 150-158. doi: $10.1159 / 000325264$

Oomura, Y., Kimura, K., Ooyama, H., Maeno, T., Iki, M., and Kuniyoshi, M. (1964). Reciprocal activities of the ventromedial and lateral hypothalamic areas of cats. Science 143, 484-485.

Oomura, Y., Ooyama, H., Sugimori, M., Nakamura, T., and Yamada, Y. (1974). Glucose inhibition of the glucose-sensitive neurone in the rat lateral hypothalamus. Nature 247, 284-286.

Petersen, S. (1978). Effects of testosterone upon feeding in male mice. Anim. Behav. $26,945-952$

Phoenix, C. H., Goy, R. W., Gerall, A. A., and Young, W. C. (1959). Organizing action of prenatally administered testosterone propionate on the tissues mediating mating behavior in the female guinea pig. Endocrinology 65, 369-382.

Qu, D., Ludwig, D. S., Gammeltoft, S., Piper, M., Pelleymounter, M. A., Cullen, M. J., et al. (1996). A role for melanin-concentrating hormone in the central regulation of feeding behaviour. Nature 380, 243-247. doi: 10.1038/380 $243 \mathrm{a} 0$

Robin, J. P., Decrock, F., Herzberg, G., Mioskowski, E., Le Maho, Y., Bach, A., et al. (2008). Restoration of body energy reserves during refeeding in rats is dependent on both the intensity of energy restriction and the metabolic status at the onset of refeeding [corrected]. J Nutr 138, 861-866.

Sakamaki, R., Uemoto, M., Inui, A., Asakawa, A., Ueno, N., Ishibashi, C., et al. (2005). Melanin-concentrating hormone enhances sucrose intake. Int J Mol Med 15, 1033-1039. doi: 10.3892/ijmm.15.6.1033

Sakurai, T., Amemiya, A., Ishii, M., Matsuzaki, I., Chemelli, R. M., Tanaka, H., et al. (1998). Orexins and orexin receptors: a family of hypothalamic neuropeptides and $\mathrm{G}$ protein-coupled receptors that regulate feeding behavior. Cell 92, 1 page following 696.

Santollo, J., and Eckel, L. A. (2008). The orexigenic effect of melanin-concentrating hormone $(\mathrm{MCH})$ is influenced by sex and stage of the estrous cycle. Physiol. Behav. 93, 842-850. doi: 10.1016/j.physbeh.2007.11.050

Schneider, J. E. (2006). Metabolic and hormonal control of the desire for food and sex: implications for obesity and eating disorders. Horm. Behav. 50, 562-571. doi: 10.1016/j.yhbeh.2006.06.023 
Schwarz, J. M., and McCarthy, M. M. (2008a). Cellular mechanisms of estradiolmediated masculinization of the brain. J. Steroid Biochem. Mol. Biol. 109, 300-306. doi: 10.1016/j.jsbmb.2008.03.012

Schwarz, J. M., and McCarthy, M. M. (2008b). Steroid-induced sexual differentiation of the developing brain: multiple pathways, one goal. J. Neurochem. 105, 1561-1572. doi: 10.1111/j.1471-4159.2008.05384.x

Sheng, M., Mcfadden, G., and Greenberg, M. E. (1990). Membrane depolarization and calcium induce c-fos transcription via phosphorylation of transcription factor CREB. Neuron 4, 571-582.

Sheriff, S., Chance, W. T., Fischer, J. E., and Balasubramaniam, A. (1997). Neuropeptide $\mathrm{Y}$ treatment and food deprivation increase cyclic AMP response element-binding in rat hypothalamus. Mol. Pharmacol. 51, 597-604.

Shimada, M., Tritos, N. A., Lowell, B. B., Flier, J. S., and Maratos-Flier, E. (1998). Mice lacking melanin-concentrating hormone are hypophagic and lean. Nature 396, 670-674. doi: 10.1038/25341

Shimizu, H., and Bray, G. A. (1993). Effects of castration, estrogen replacement and estrus cycle on monoamine metabolism in the nucleus accumbens, measured by microdialysis. Brain Res. 621, 200-206.

Shimizu-Albergine, M., Ippolito, D. L., and Beavo, J. A. (2001). Downregulation of fasting-induced cAMP response element-mediated gene induction by leptin in neuropeptide Y neurons of the arcuate nucleus. J. Neurosci. 21, $1238-1246$.

Sousa-Ferreira, L., De Almeida, L. P., and Cavadas, C. (2014). Role of hypothalamic neurogenesis in feeding regulation. Trends Endocrinol. Metab. 25, 80-88. doi: 10.1016/j.tem.2013.10.005

Swaab, D. F., Chung, W. C., Kruijver, F. P., Hofman, M. A., and Ishunina, T. A. (2001). Structural and functional sex differences in the human hypothalamus. Horm. Behav. 40, 93-98. doi: 10.1006/hbeh.2001.1682

Tarttelin, M. F., and Gorski, R. A. (1971). Variations in food and water intake in the normal and acyclic female rat. Physiol. Behav. 7, 847-852.

Uhley, V. E., Zhong, S., Guo, F., Buison, A., Savona, L., Watkins, A., et al. (1997). Differential gender response produced by meal and ad lib feedings of a high-fat diet in Osborne-Mendel rats. Physiol. Behav. 62, 617-622.

Valenstein, E. S., Cox, V. C., and Kakolewski, J. W. (1969). Sex differences in hyperphagia and body weight following hypothalamic damage. Ann. N.Y. Acad. Sci. 157, 1030-1048.

Valenstein, E. S., Kakolewski, J. W., and Cox, V. C. (1967). Sex differences in taste preference for glucose and saccharin solutions. Science 156, 942-943.
Varma, M., Chai, J. K., Meguid, M. M., and Yang, Z. J. (2001). Gender differences in tumor-induced anorectic feeding pattern in Fischer-344 rats. Physiol. Behav. 74, 29-35. doi: 10.1016/S0031-9384(01)00569-8

Wade, G. N., Schneider, J. E., and Li, H. Y. (1996). Control of fertility by metabolic cues. Am. J. Physiol. 270, E1-E19.

Wang, T., Hung, C. C., and Randall, D. J. (2006). The comparative physiology of food deprivation: from feast to famine. Annu. Rev. Physiol. 68, 223-251. doi: 10.1146/annurev.physiol.68.040104.105739

Wilson, C. A., and Davies, D. C. (2007). The control of sexual differentiation of the reproductive system and brain. Reproduction 133, 331-359. doi: 10.1530/REP06-0078

Witkin, J. W., Xiao, E., Popilskis, S., Ferin, M., and Silverman, A. J. (1994). FOS expression in the gonadotropin-releasing hormone $(\mathrm{GnRH})$ neuron does not increase during the ovarian steroid-induced GnRH surge in the rhesus monkey. Endocrinology 135, 956-961. doi: 10.1210/endo.135.3.8070392

Wu, M. V., and Shah, N. M. (2011). Control of masculinization of the brain and behavior. Curr. Opin. Neurobiol. 21, 116-123. doi: 10.1016/j.conb.2010.09.014

Xu, Y., Nedungadi, T. P., Zhu, L., Sobhani, N., Irani, B. G., Davis, K. E., et al. (2011) Distinct hypothalamic neurons mediate estrogenic effects on energy homeostasis and reproduction. Cell Metab. 14, 453-465. doi: 10.1016/j.cmet.2011.08.009

Zammaretti, F., Panzica, G., and Eva, C. (2007). Sex-dependent regulation of hypothalamic neuropeptide Y-Y1 receptor gene expression in moderate/high fat, high-energy diet-fed mice. J. Physiol. 583, 445-454. doi: 10.1113/jphysiol.2007.133470

Zandian, M., Ioakimidis, I., Bergh, C., Leon, M., and Sodersten, P. (2011). A sex difference in the response to fasting. Physiol. Behav. 103, 530-534. doi: 10.1016/j.physbeh.2011.04.009

Conflict of Interest Statement: The authors declare that the research was conducted in the absence of any commercial or financial relationships that could be construed as a potential conflict of interest.

Copyright (C) 2015 Fukushima, Hagiwara, Fujioka, Kimura, Akema and Funabashi. This is an open-access article distributed under the terms of the Creative Commons Attribution License (CC BY). The use, distribution or reproduction in other forums is permitted, provided the original author(s) or licensor are credited and that the original publication in this journal is cited, in accordance with accepted academic practice. No use, distribution or reproduction is permitted which does not comply with these terms. 